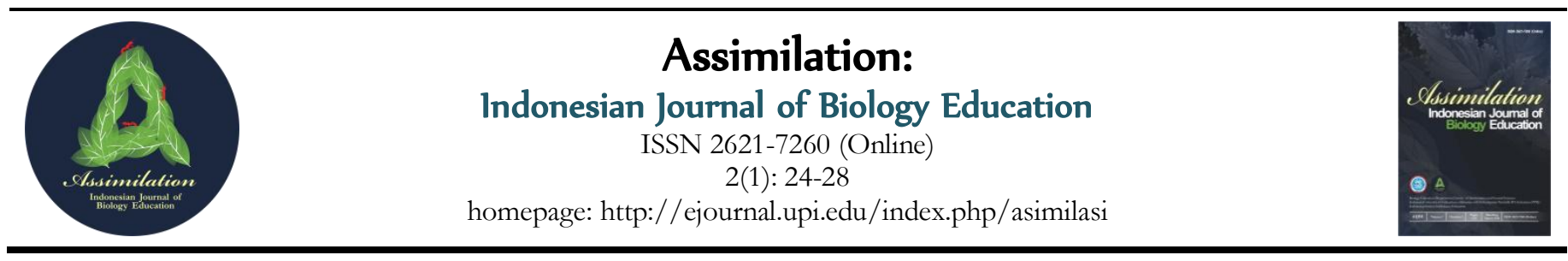

\title{
Penerapan Self Generated Analogy sebagai Upaya Meningkatkan Kemampuan Berpikir Kreatif Siswa SMA pada Materi Sistem Peredaran Darah (Applying Self Generated Analogy to Improve Senior Highschool Students' Creative Thinking in Circulation System Lesson)
}

\author{
Fiqa Islamiati*, Kusnadi, Suhara \\ Departemen Pendidikan Biologi FPMIPA Universitas Pendidikan Indonesia, Jl. Dr. Setiabudhi No. 229 Bandung, Indonesia \\ *Corresponding author: fiqaislamiati@student.upi.edu
}

Received: 24 January 2019 - Accepted: 29 March 2019 - Published: 30 March 2019

\begin{abstract}
The aim of the reseatch want to analyze the improvement of students' creative thinking ability in blood circulation system by applying self generated analogy. This research was done in a Public High School in Cimahi and was applied to two classes, the experiment class with 36 students and control class with 31 students. The method used for this research was quasi experimental. The samplewas selected by purposive technique. The data werecollectedby doing creative thinking ability test in form of essay, students' questionnaire, and classroom observation. The difference of creative thinking ability was reviewed form the result of the test given before and after treatment, and the improvement was seen using $\mathrm{N}$-gain. The test result was compared by doing a statistical test using a software program, SPSS statistic 16.The result of the research shows that there is a significant difference in the creative thinking ability between the treatment and control group class, with a high improvement in the treatment class and medium improvement in control class. The average of posttest in the self generated analogy class is 83,2 higher than the control class, which is 65,9 . The $\mathrm{N}$-gain result of creative thinking ability in the treatment class is around 0,59 (high category) whereas the control class is around 0,28 (low category). It shows that self generated analogy improves students' creative thinking ability. The questionnaire showpositive response from students that self generated analogy is able to improve students creative thinking abilityin teaching circulation system.
\end{abstract}

Keywords creative thinking, self generated analogy, verification, circulatory system

\begin{abstract}
ABSTRAK Penelitian ini bertujuan untuk menganalisis peningkatan kemampuan berpikir kreatif siswa pada materi sistem peredaran darah melalui penerapan self generated analogy. Penelitian ini dilakukan terhadap siswa SMA Negeri di Cimahi sebanyak dua kelas, kelas eksperimen berjumlah 36 siswa dan kelas kontrol berjumlah 31 siswa. Metode yang digunakan adalah quasi experimental. Teknik pengambilan sampel dilakukan dengan cara purposif. Data penelitian diperoleh dari tes kemampuan berpikir kreatif berupa soal uraian, angket respon siswa, lembar kerja siswa, dan observasi aktivitas siswa.Perbedaan kemampuan berpikir kreatif ini ditinjau dari hasil tes sebelum dan sesudah pembelajaran diberikan dan dilihat peningkatannya menggunakan $\mathrm{N}$-gain. Hasil tes dibandingkan dengan melakukan uji statistik menggunakan software program SPSS statistic 16. Hasil penelitian menunjukkan terdapat perbedaan signifikan antara kemampuan berpikir kreatif siswa pada kelas eksperimen dan kontrol, dengan peningkatan termasuk kategori tinggi pada kelas eksperimen dan kategori sedang pada kelas kontrol. Rata-rata nilai posttest padakelas self generated analogy adalah 83,2 lebih besar daripada kelas kontrol yaitu 65,9.Perolehan N-gain kemampuan berpikir kreatif yang dilakukan siswa pada kelas self generated analogy sekitar 0,59 (kategori tinggi), pada kelas kontrol sekitar 0,28 (kategori rendah). Hal tersebut menunjukkan bahwa self generated analogy meningkatkan kemampuan berpikir kreatif siswa. Hasil angket menunjukkan respon positif bahwa penerapan self generated analogy pada materi sistem peredaran darahmampu meningkatkan kemampuan berpikir kreatif siswa.
\end{abstract}

Kata kunci berpikir kreatif, self generated analogy, sistem peredaran darah

\section{PENDAHULUAN}

Dalam proses belajar mengajar, kemampuan berpikir jarang dilatih terutama kemampuan dalam berpikir kreatif. Hal ini tidak sejalan dengan Standar Nasional Pendidikan (PP No. 19 Tahun 2005 Bab IV tentang Standar Proses Pasal 19) menyebutkan bahwa pembelajaran pada satuan pendidikan diselenggarakan secara interaktif, inspiraif, menyenangkan, menantang, memotivasi peserta didik untuk berpartisipasi aktif, serta memberikan ruang yang cukup bagi prakarsa, kreativitas, dan kemandirian sesuai dengan bakat, minat, dan perkembangan fisik serta psikologis peserta didik (learning how to learn).

Munandar (2001) berpendapat bahwa pengajaran di sekolah pada umumnya hanya melatih proses berpikir konvergen, terbatas pada penalaran verbal dan pemikiran logis. Sehingga siswa akan terbiasa dengan berpikir konvergen dan bila dihadapkan pada suatu masalah siswa 
akan mengalami kesulitan memecahkan masalah secara kreatif. Rofi'udin (dalam Arnyana, 2009) menyatakan bahwa terjadi keluhan tentang rendahnya kemampuan berpikir kritis dan kreatif yang dimiliki oleh peserta didik karena pendidikan berpikir belum ditangani dengan baik. Oleh karena itu, penanganan kemampuan berpikir kritis dan kreatif sangat penting untuk diterapkan dalam setiap pembelajaran.

Melalui proses belajar mengajar yang diberikan di sekolah, siswa diharapkan memiliki kemampuan berpikir untuk menyelesaikan suatu masalah.Untuk menyelesaikan masalah tersebut, siswa harus memiliki kemampuan berpikir untuk menentukan dan mengatasi berbagai solusi dari permasalahan tersebut. Siswa akan dapat menentukan berbagai alternatif pemecahan masalah yang ia hadapi apabila siswa mampu melihat berbagai kemungkinan yang mengarah pada pemecahan masalah tersebut ( $\mathrm{Hu} \&$ Adey, 2002). Hal tersebut berkaitandengan kemampuan kreativitas yang dimiliki siswa. Namun, permasalahan dalam pendidikan pada saat ini adalah rendahnya pengembangan kreativitas yang disebakaan karena pembelajaran di sekolah hanya dituntut untuk menguasai konsep dan materi tertentu sehingga kemampuan berpikir kritis dan kreatif jarang dilatih. Amabile (dalam Lederman, 2015) menyebutkan bahwa kreativitas umumnya didefinisikan sebagai sebuah kemampuan untuk menghasilkan ide-ide dan solusi yang keduanya asli dan sesuai.

Kreativitas dibutuhkan ketika siswa menciptakan sesuatu yang baru atau menciptakan sesuatu yang relatif berbeda dari yang sudah ada sebelumnya.Pada saat siswa berusaha untuk menyelesaikan suatu permasalahan, kreativitas dibutuhkan dalam mengeksplorasi pengetahuan dan mengimajinasikan berbagai rute alternatif atas permasalahan tersebut ( $\mathrm{Hu} \&$ Adey, 2002). Oleh karena itu, kreativitas perlu dikembangkan dalam proses pembelajaran. Biologi merupakan salah satu mata pelajaran yang memiliki konsep yang abstrak dan sulit (Sudesti et al., 2014). Materi dalam pelajaran biologi juga memiliki tingkat kesulitan yang berbeda-beda. Sistem peredaran darah adalah salah satu materi yang tersulit dan materi tersebut membutuhkan metode pembelajaran yang dapat dengan mudah dipahami dengan baik oleh peserta didik. Dalam proses penyampaian materi ini harus diajarkan kepada peserta didik secara kreatif dan inovatif, agar peserta didik tidak merasa bosan dan jenuh serta keinginan untuk belajar menjadi lebih meningkat daripada sebelumnya. Proses peredaran darah yang terjadi di dalam tubuh manusiapun tidak dapat dilihat secara langsung oleh peserta didik. Oleh karena itu, diperlukan adanya inovasi dalam melakukan proses pembelajaran mengenai sistem peredaran darah yang diterapkan oleh guru agar siswa menjadi mudah dalam mempelajarinya dan memahami materi tersebut.

Salah satu inovasi pembelajaran yang dapat diterapkan pada materi sistem peredaran darah adalah pembelajaran dengan menggunakan analogi. Pembelajaran menggunakan analogi merupakan pembelajaran yang akan mendorong siswa untuk memvisualisasikan konsep yang hendak dipelajari (Glynn, 1994). Siswa melibatkan imajinasi dalam proses visualisasi ini. Rachmawati (2010) menyebutkan bahwa melatih imajinasi merupakan salah satu cara yang dapat dilakukan untuk dapat mengembangkan kreativitas. Alasan menggunakan analogi dalam pembelajaran yang abstrak yaitu untuk mengetahui sumber domain yang lebih konkrit dan dikenal siswa. Siswa membuat analogi berdasarkan pengetahuan awal sehingga tingkat pemahaman mereka akan terlihat dari hasil analogi yang dibuat. Selama siswa membuat analogi akan diajak untuk mengonstruksi pengetahuan baru yang mereka dapat selama membuat analogi tersebut. Kemampuan berpikir kreatif siswa dapat dilatih dalam pembelajaran menggunakan analogi, karena siswa dituntut untuk berimajinasi dan menemukan konsep analog yang memiliki kemiripan dengan konsep target.

Penerapan analogi dalam pembelajaran bertujuan untuk memudahkan siswa memahami suatu konsep yang dipelajari. Dalam proses belajar mengajar, seorang guru tanpa disadari sering menyisipkan analogi-analogi pada materi tertentu. Guru sering menyampaikan analogi pada saat mereka melihat siswa kesulitan memahami konsep (Coll \& Treagust, 2008). Beberapa penerapan analogi pada pembelajaran Biologi terbukti efektif dan memudahkan siswa dalam belajar (Harrison \& Coll, 2008). Oleh karena itu, Coll \& Treagust (2008) menyebutkan bahwa analogi efektif pada beberapa pelajaran, namun tidak pada pelajaran yang lain.

Pada umumnya, dalam kegiatan belajar mengajar, analogi yang digunakan dalam pembelajaran adalah analogi yang sudah disediakan oleh guru, seperti halnya penelitian yang dilakukan oleh Suciyanti (2011). Analogi yang diterapkan dalam proses pembelajaran sudah disediakan oleh guru, sehingga kemampuan dan imajinasi siswa menjadi lebih terbatas karena pemikiran siswa sudah diarahkan untuk memvisualisasikan analogi tertentu. Kemampuan imajinasi yang dimiliki oleh siswa sangat berbeda-beda, hal tersebut sangat mungkin dapat dilatih dan dimanfaatkan untuk siswa membuat analoginya sendiri. Coll \& Treagust (2008) mengungkapkan bahwa berdasarkan teori konstruktivisme, pembelajaran lebih baik berpusat pada siswa daripada berpusat pada guru. Berdasarkan hal ini berarti siswa seharusnya terlibat aktif dalam membuat analogi ataupun merekonstruksi analogi yang disampaikan oleh guru untuk disesuaikan dengan pengalaman siswa itu sendiri.

\section{METODE}

Metode penelitian yang digunakan pada penelitian ini adalah eksperimen. Penelitian ini dilakukan di SMA Negeri 3Cimahi. Partisipan pada penelitian ini adalah siswa kelas XI IPA 5 sebagai kelas eksperimen dan kelas XI IPA 6 sebagai kelas kontrol. Siswa yang berpartisipasi dalam penelitian ini sebanyak 67 siswa yang terdiri dari 36 siswa pada kelas eksperimen dan 31 siswa pada kelas kontrol. Pemilihan kelas ini dilakukan secara purposive sampling.

Penelitian ini dilakukan dalam empat tahap yaitu tahap pertama untuk mengetahui kemampuan awal siswa, guru memberikan soal pretest berupa tes uraian sebagai salah satu instrumen untuk mengukur kemampuan berpikir kreatif siswa. Pada tahap kedua, kegiatan pembelajaran dilakukan dikelas kontrol menggunakan sistem pembelajaran kontrol sedangkan pada kelas eksperimen menggunakan penerapan 
self generated analogy. Kedua kelas tersebut belajar tentang sistem peredaran darah. Pada tahap ketiga, di kelas eksperimen guru membagi siswa menjadi beberapa kelompok kecil. Di kelas kontrol siswa diberikan media yang ada di sekolah berupa media yang ada di sekolah sedangkan di kelas eksperimen siswa harus membuat self generated analogy. Tahap keempat, setelah dilaksanakan kegiatan pembelajaran, siswa diberikan lagi soal yang sama saat diberikan pretest. Soal tersebut berisi tentang pernyataan mengenai konsep sistem peredaran darah sesuai dengan indikator kemampuan berpikir kreatif (Tabel 1).

Tabel 1. Kisi-Kisi Kemampuan Berpikir Kreatif

\begin{tabular}{|c|c|}
\hline Indikator & Perilaku siswa yang diidentifikasi \\
\hline $\begin{array}{l}\text { Berpikir lancar } \\
\text { (fluency) }\end{array}$ & $\begin{array}{l}\text { a. Lancar dalam mengemukakan } \\
\text { jawaban. }\end{array}$ \\
\hline & $\begin{array}{l}\text { b. Mampu memberikan jawaban secara } \\
\text { tepat mengenai objek yang diamati. }\end{array}$ \\
\hline $\begin{array}{l}\text { Berpikir } \\
\text { luwes(flexibility) }\end{array}$ & $\begin{array}{l}\text { Memberikan macam-macam penafsiran } \\
\text { terhadap suatu gambar. }\end{array}$ \\
\hline $\begin{array}{l}\text { Berpikir asli } \\
\text { (originality) }\end{array}$ & $\begin{array}{l}\text { Membuat kombinasi-kombinasi dari } \\
\text { bagian atau unsur. }\end{array}$ \\
\hline $\begin{array}{l}\text { Berpikir merinci } \\
\text { (elaboration) }\end{array}$ & $\begin{array}{l}\text { Menambahkan atau memperinci detil- } \\
\text { detil dari suatu objek, gagasan, gambar } \\
\text { atau situasi sehingga menjadi lebih } \\
\text { menarik dan jelas. }\end{array}$ \\
\hline
\end{tabular}

Cara penggunaan self generated analogy untuk meningkatkan kemampuan berpikir kreatif siswa SMA pada materi sistem peredaran darah, pada pertemuan pertama yang dilakukan oleh guru adalah melakukan pembelajaran pembiasaan dengan menggunakan analogi pada materi sistem respirasi manusia, di akhir pembelajaran guru menugaskan siswa untuk membawa alat-alat dan bahan-bahan yang akan digunakan untuk membuat analogi pada pertemuan selanjutnya.

Pada pertemuan kedua, guru memberikan sedikit ulasan materi mengenai sistem peredaran darah dengan pokok bahasan organ jantung, komponen-komponen darah, mekanisme sistem peredaran darah, kelainan sistem peredaran darah dan golongan darah dengan menggunakan power point, selanjutnya siswa dibagi menjadi beberapa kelompok, pada pertemuan sebelumnya guru menugaskan siswa untuk membawa alat-alat dan bahan-bahan yang akan digunakan untuk membuat self generated analogy mengenai materi sistem peredaran darah, lalu guru membagikan LKS self generated analogy untuk didiskusikan setiap kelompok, guru menjelaskan cara pengisian LKS self generated analogy, pada saat siswa berdiskusi mengenai $\mathrm{lks}$ self generated analogy guru menjelaskan dan mengarahkan mengenai analogiyang akan dibuat oleh siswa, Setiap kelompok ditugaskan untuk berdiskusi mengenai rancangan self generated analogy yang akan mereka buat, guru mengkonfirmasi hasil diskusi kelompok, guru menugaskan siswa untuk membaca materi sistem peredaran darah dan membuat self generated analogy di rumah secara berkelompok dan membawa analogi yang telah dibuat pada pertemuan selanjutnya untuk dipresentasikan dan didiskusikan.

Pada pertemuan ketiga, guru mengulas kembali sedikit materi yang telah dijelaskan pada pada pertemuan sebelumnya mengenai bagian-bagian organ jantung dan fungsinya, mekanisme sistem peredaran darah, kelainan dan penyakit pada sistem peredaran darah, serta golongan darah dengan menggunakan power point. Setiap perwakilan kelompok mempresentasikan hasil dari self generated analogy yang telah dibuat dan LKS yang telah didiskusikan. Setiap kelompok melakukan diskusi dengan cara menyanggah atau menambahkan hasil dari self generated analogy yang dipresentesaikan oleh kelompok lain. Setelah semua kelompok telah selesai mempresentasikan hasil self generated analogy, kemudian guru mengkonfirmasi dan menyimpulkan hasil diskusi, Setiap kelompok mengumpulkan LKS dan self generated analogy yang telah dibuat.

\section{HASIL DAN PEMBAHASAN}

Data mengenai kemampuan berpikir kreatif siswa didapatkan melalui tes awal (pretest) yang diberikan kepada siswa sebelum pembelajaran dan melalui tes akhir (posttest) yang diberikan setelah pembelajaran dengan menggunakan penerapan self generated analogy pada kelas eksperimen. Data yang didapat berupa skor dengan rentang 0-32. Perolehan skor ini menunjukkan pola berpikir kreatif yang dimiliki oleh siswa.

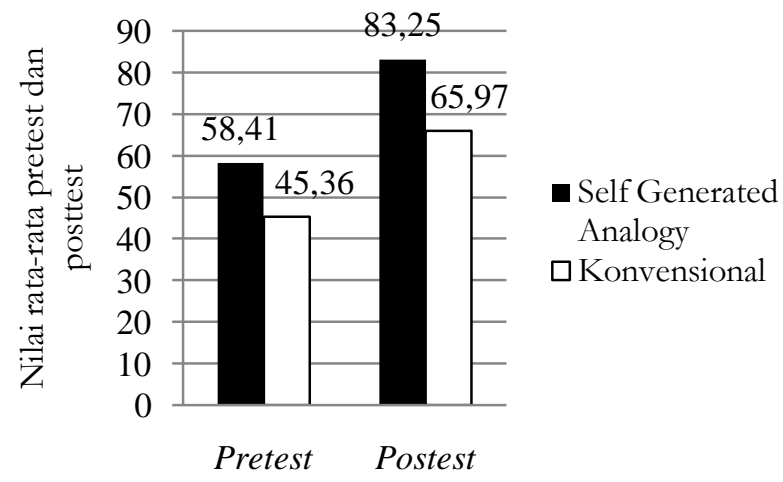

Gambar 1. Perbandingan Nilai Pretest dan Posttest pada Kelas Self Generated Analogy dan Kontrol

Berdasarkan Gambar 1 dapat diketahui bahwa, dapat dinyatakan bahwa, rata-rata nilai posttest lebih tinggi daripada rata-rata nilai pretest. Rata-rata nilai posttest yaitu 83,2 sedangkan rata-rata nilai pretest yaitu 65,9 yang menunjukkan adanya peningkatan kemampuan berpikir kreatif siswa yang cukup baik. Hal ini disebabkan karena nilai setiap aspek pada setiap siswa sangat bervariasi. Hal tersebut sependapat dengan Kim (2006) yang mengemukakan bahwa setiap orang sebenarnya memiliki kemampuan berpikir kreatif, tetapi potensi kreatif tersebut berbeda-beda. Tidak ada orang yang sama sekali tidak memiliki kreativitas atau kemampuan berpikir kreatif, yang diperlukan hanyalah cara untuk mengembangkannya. Hasil posttest perbandingan pada tiap indikator kemampuan berpikir kreatif dapat dilihat pada Gambar 2.

Pada Gambar 2 dapat dilihat bahwa hasil posttest pada semua indikator kemampuan berpikir kreatif pada kelas self generated analogy maupun kelas kontrol mengalami peningkatan. Pada kelas self generated analogy indikator flexibility memeroleh nilai yang paling tinggi yaitu sebesar 96,8. Sedangkan pada kelas kontrol indikator elaboration memeroleh nilai yang paling tinggi yaitu sebesar 67,7. Berdasarkan hasil rata-rata pretest dan posttest pada kelas 
yang menerapkan self generated analogy menunjukkan bahwa pembelajaran dengan analogi dapat mengembangkan kemampuan berpikir kreatif siswa lebih baik daripada metode ceramah hal ini sejalan dengan yang dikatakan oleh Harrison \& Coll (2013) yang menyatakan bahwa analogi merupakan agen perubah konseptual yang efektif karena dapat meningkatkan pemahaman dengan menghubungkan antara konsep-konsep ilmu dengan pengalaman siswa serta membantu siswa dalam memvisualisasikan hal yang abstrak.

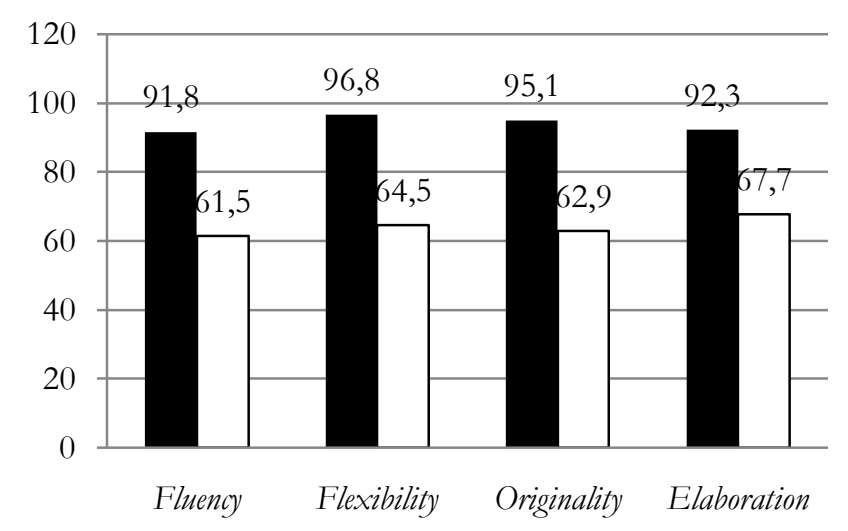

- Analogy $\square$ Konvensional

Gambar 2. Hasil Posttest Perbandingan tiap Indikator Kemampuan Berpikir Kreatif

Setelah diterapkannya pembelajaran penerapan self generated analogy, rata-rata nilai pada setiap indikator kemampuan berpikir kreatif ini meningkat. Menurut buku yang diedit oleh Harrison et al.,(2013) dikatakan bahwa mengajar dengan analogi dapat lebih menyenangkan dan memotivasi murid. Suasana pembelajaran yang kondusif dan menyenangkan tentunya akan mempengaruhi pemahaman siswa terhadap meteri yang diajarkan. Penggunaan self generated analogy mampu memberikan gambaran dan perumpamaan tentang konsep sistem peredaran darah dengan hal yang sudah mereka ketahui dan kenal sebelumnya, dalam hal ini perumpamaan sistem peredaran darah dengan menggunakan botol, selang, styrofoam, pewarna makanan berwarna merah. Hal tersebut sejalan dengan yang dikatakan oleh Harrison \& Coll (2013) yang menyatakan bahwa analogi merupakan agen perubah konseptual yang efektif karena dapat meningkatkan pemahaman dengan menghubungkan antara konsepkonsep ilmu dengan pengalaman siswa serta membantu siswa dalam memvisualisasikan hal yang abstrak.

Kemiripan yang ditemukan dalam perumpamaan sistem peredaran darah demgan alat alat seperti botol, selang, styrofoam dan lainnya menghadirkan ketertarikan tersendiri bagi siswa terhadap pembelajaran. Hal tersebut sesuai dengan penelitian Gentner yang menunjukkan bahwa kemiripan menyebabkan para murid tertarik pada anlogi, dan membantu mereka mencari hubungan yang ada antara situasi sehari-hari dengan kosnep sains (Harrison, 2013).

Penggunaan perumpamaan dengan hal-hal yang sudah siswa ketahui sebelumnya dapat mempermudah siswa untuk memehami konsep yang diajarkan.Seperti yang dijelaskan Slavin dalam jurnal yang ditulis oleh Harjono (2006), bahwa analogi mengaitkan konsep-konsep baru dengan informasi yang telah dipahami.Penggunaan analogi dapat membantu siswa dalam memahami suatu pelajaran atau bacaan yang diberikan. Hasil perolehan N-gain setelah dilakukan pengujian statistika menunjukkan bahwa peningkatan kemampuan berpikir kreatif kedua kelas menunjukkan perbedaan yang signifikan.Meskipun memiliki data yang berbeda signifikan tetapi kedunya mengalami peningkatan jika dilihat dari kemampuan awal kedua kelas tersebut.

Pada kelas yang menerapkan self generated analogy memiliki nilai $\mathrm{N}$-gain yaitu sebesar 0,59 yang berada dalam kategori sedang, sedangkan pada kelas kontrol memiliki nilai $\mathrm{N}$-gain 0,28 berada dalam kategori rendah. Dari peningkatan tersebut dapat dilihat bahwa kelas self generated analogy mengalami peningkatan $\mathrm{N}$-gain yang lebih tinggi jika dibandingkan dengan kelas kontrol. Selain menggunakan instrument kemampuan berpikir kreatif berupa pretest dan posttest, penerapan self generated analogy juga didukung oleh Lembar Kerja Siswa, self generated analogy dan obervasi aktifitas siswa selama proses pembelajaran penerapan self generated analogy.

Lembar Kerja Siswa self generated analogy merupakan lembar kerja siswa yang digunakan pada saat pembuatan self generated analogy yang bertujuan untuk mengetahui rancangan analogi yang akan dibuat oleh siswa. LKS tersebut berisi judul, tujuan, tabel hasil pengamatan dengan kolom berupa daftar nama struktur, analogi dan fungsi organ, nama alat-alat dan bahan-bahan yang digunakan dalam pembuatan analogi, langkah kerja, kesimpulan, dan pertanyaan-pertanyaan yang berkaitan dengan self generated analogy pada konsep sistem peredaran darah. Hasil penilaian lembar kerja siswa menunjukkan bahwa rata-rata keseluruhan kelompok yaitu 85. Hasil penilaian self generated analogy menunjukkan bahwa rata-rata keseluruhan kelompok yaitu 87. Kelompok 1 dan 2 membahas dan membuat analogi mengenai mekanisme sistem peredaran darah, kelompok 3 dan 4 membahas dan membuat analogi mengenai komponen sel-sel darah, kelompok 5 dan 6 membahas dan membuat analogi mengenai kelainan sistem peredaran darah.

Selanjutnya dilakukan analisis hubungan untuk mengetahui apakah terdapat hubungan penerapan self generated analogy demgan kemampuan berpikir kreatif pada materi sistem peredaran darah. Berdasarkan hasil analisis uji korelasi penerapan self generated analogy dengan kemampuan berpikir kreatif siswa pada materi sistem peredaran darah menunjukkan adanya hubungan antara penerapan self generated analogy dengan kemampuan berpikir kreatif siswa dengan nilai signifikasi 0,000 . Nilai koefisien korelasi $\left(r^{2}\right)$ sebesar 0,559 yang menunjukkan terdapat hubungan penerapan self generated analogy dengan kemampuan berpikir kreatif siswa dalam kategori sedang karena berada pada rentang 0,40 - 0,599 (Sugiyono, 2007). Selain itu menunjukkan hubungan yang berkolerasi positif $(+)$ artinya kenaikan rata-rata penerapan self generated analogy dengan rata-rata kemampuan berpikir kreatif. Sedangkan $45 \%$ dipengaruhi faktor-faktor lainnya seperti pada saat akan dilaksanakan ulangan siswa belajar dengan giat, lalu dipengaruhi juga oleh faktor internal, yaitu kondisi 
psikologi seperti minat, kecerdasan, bakat, motivasi, kemudian faktor fisiologi siswa seperti kesehatan yang prima, kelelahan, selain itu faktor lingkungan juga berpengaruh termasuk keadaan sosial yang ada disekitar siswa.

\section{SIMPULAN}

Berdasarkan penelitian yang telah dilakukan dapat disimpulkan bahwa penerapan self generated analogy dalam pembelajaran biologi dapat meningkatkan kemampuan berpikir kreatif siswa. Dari keempat indikator kemampuan berpikir kreatif yang diukur, kemampuan berpikir luwes (flexibility) memiliki tingkat kemampuan tertinggi dengan indeks $N$-gain yang diperoleh sebesar 0,59 dengan kategori tinggi pada pembelajaran yang menerapkan self generated analogy.

\section{REFERENSI}

Arnyana, I. B. P. (2009). Pengaruh Penerapan Strategi Pembelajaran Inovatif pada Pelajaran Biologi Terhadap Kemampuan Berpikir Kreatif Siswa SMA. Jurnal Pendidikan dan Pengajaran. No. 3

Coll, R. K \& Treagust D.F. (2008). Inquiry-based teacherand student-generated analogies. Dalam Harrison, A. G. \& Coll, R. K. (Penyuting), Using analogies in middle and secondary science classrooms: the FAR guide an interesting way to teach with analogies (hlm. 66-82). California Corwin Press.

Glynn, S. M. (1994). Teaching science with analogies a strategy for teachers and textbook authors. Athens: National Reading Research Center.

Harjono, A. (2006). Strategi penerapan belajar pada Model pengajaran langsung (Direct Instruction). Jurnal Dinamika Pendidikan. 2(1).
Harrison, A. G. (2008). Multiple analogies are better than one-size-fits-all analogies. Dalam Harrison, A. G. \& Coll, R. K. (Penyunting), Using analogies in middle and secondary science classrooms: the FAR guide- an interesting way to teach with analogies (hlm. 46-65). California: Corwin Press.

Harrison, A. G \& Coll, R. K. (2013). Using analogies in middle and secondary science classrooms: the FAR guide an interesting way to teach with analogies. California: Corwin Press.

Hu, W. \& Adey, P. (2002).A scientific creativity test for secondary school students.International Journal of Science Education, 24(4), hlm. 389-403.

Kim, K. H. 2006. Can We Trust Creativity Test? A Review of the Torrance Tests of Creative Thinking (TTCT), artikel dalam Crea-tivity Research Journal, Vol. 18(1), pp. 3-14.

Lederman, J. (2015). Urban Fads and Consensual Fictions: Creative, Sustainable, and Competitive City Policies in Buenos Aires. City and Community. 14 (1). hlm. 47 67.

Munandar, U. (2009). Pengembangan Kreativitas Anak Berbakat. Jakarta: PT.Gramedia Widiasarana Indonesia.

Suciyanti, F. (2011). Pengaruh penggunaan model pembelajaran analogi terhadap hasil belajar siswa (studi eksperimen pada siswa kelas XI IPA pokok bahasan sistem pertahanan tubuh di SMA Negeri 9 Bandung). (Skripsi).Universitas Pasundan, Bandung.

Sudesti, R., Sudargo, F. \& Kusumastuti, M. N. (2014). Penerapan Pembelajaran Berbasis Praktikum Untuk Meningkatkan Penguasaan Konsep dan Keterampilan Proses Sains Siswa SMP Pada Subkonsep Difusi Osmosis. Formica Education Online, 1(1), hlm. 1-11. 